\title{
National Guidelines for Bridge Information Modeling and Automation
}

\author{
$\underline{\text { Rauno Heikkilä * }}$ \\ Department of Mechanical Engineering, Construction Technology Research Center, \\ University of Oulu, Oulu, Finland \\ * Corresponding author (rauno.heikkila@oulu.fi)
}

\begin{abstract}
Purpose National bridge information modeling guidelines have been developed in Finland at the behest of the Finnish Transport Agency. The aim was to set, for the first time, national standard of producing and utilizing 3D-information modeling and automation in bridge engineering in Finland. Method In the guidelines, the terminology of different main design phases of bridges and information models is introduced. More specific information model contents and technical guidelines are then determined. A comparison is made between the Finnish guidelines and the draft Norwegian modeling guidelines. Results \& Discussion In Finland and Norway these guidelines aim to promote the use of 3D-modeling and automation in the infrastructure, including bridges, roads, and railways. There are many reasons why these types of guidelines are necessary for the industry. More international collaboration will be needed in the next development phase to arrive at comprehensive and useful guidelines and standards.
\end{abstract}

Keywords: 3D, information modeling, bridges

\section{INTRODUCTION}

Since 2001 there has been done continuous research and development work to develop the processes of bridge engineering and construction in Finland. Active work has been done in the projects called Intelligent Bridge, 5-D Bridge and 5-D Bridge2. This report introduces the results of the last 5-D Bridge2 (Development of automation into construction, repairing and maintenance of bridges) project realized in 2007-2010.

In one of the part projects of the 5-D Bridge2, i.e., Bridge Finland, general product modeling directions and specifications were developed. The next test phase is scheduled to start from the beginning of 2011. In PPP5D project, the utilization methods and possibilities of 3-D product modeling and 3-D surveying methods were modeled in a general level. In Custom Compontents project, many useful design tools were developed for bridge designer. In 3-D GPR project, the measuring methods of Ground Penetrating Radar in 3-D were studied. The Crusell Bridge in Helsinki City was the most important test case of 3D product modeling and the utilization of this information model in construction work phase. In 5-D Vt8 project, the integration of road design and bridge design was studied and tested. In addition of these part projects, the research and development work was done in several other part projects of 5-D Bridge2, of which the work by Tekla Oyj in the development of Tekla Structures software, the study of Revit Structure software by Ponvia Oy, and the development project of Destia to develop the method and process model of Design-Build model utilizing product modeling and automation features was done.

There still remain many lacks and development tasks in the development of 3-D data modeling and automation in bridge engineering. The tested design software, applications and tools are not yet ready and completed, instead they include many different lacks and problems. The utilization of product modeling more widely should be supported and even demanded by owners. The first data modeling specification developed in the 5-D Bridge2, is one of the important steps towards that direction. The information transfer and communication between road design and bridge design should also be easy and efficient.

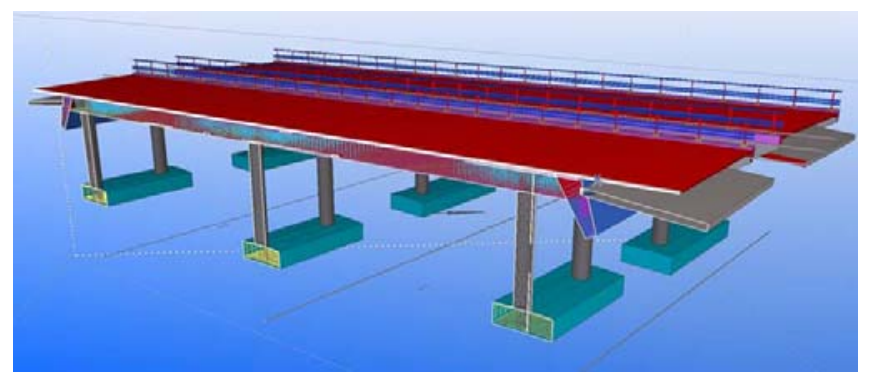

Fig.1. An example - a completed detailed product model of a bridge. The model should be ready for fully utilization in the construction processes by bridge contractor (Tekla Structures, WSP Finland Oy).

In Finland, important research and development work will be done in the new RYM Shok PRE program and the InfraFINBIM work packet, in which so called Bridge Automation project by University of 
Oulu will be realized. Also possibilities for international research and development work will be better than earlier.

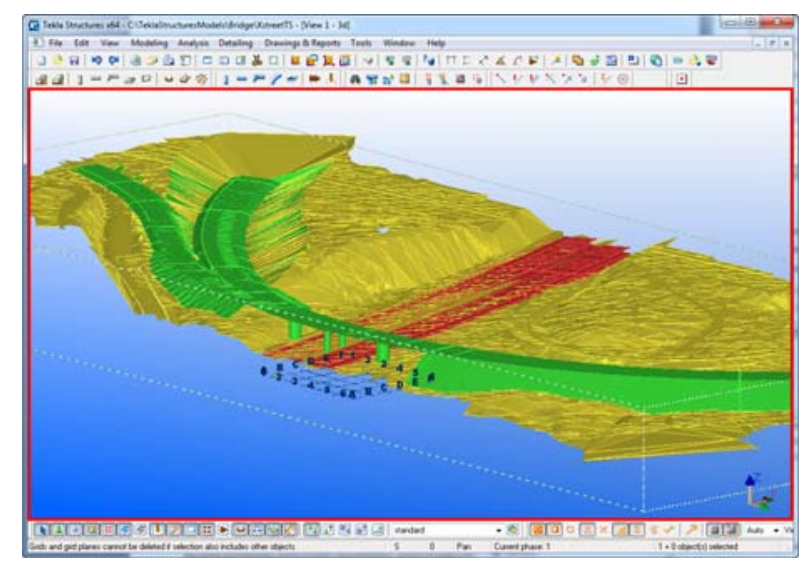

Fig.2. An example - the digital terrain model of a bridge construction site has been imported to the Bridge Modeling software (Tekla Structures, Tekla Oyj).

\section{Objective}

The objective of Bridge Finland subproject was to develop national bridge information modeling guidelines so that the work methods and models produced would be more uniform, and on the other hand still try to stay as neutral as possible to allow fast development of the field and to not block competition and introduction of new innovative methods of utilizing and producing the models.

\section{DEVELOPMENT OF THE MODELING GUIDELINES}

The study was executed by University of Oulu and Ainsinöörit Oy. The development project was started by studying and collecting any of the information how the different bridge design offices and companies been participated in the research, have done bridge design modeling. There were in all eight (8) different companies in this work (Ponvia Oy, Finnmap Consulting Oy, A-Insinöörit Oy, Slltanylund Oy, Ramboll Finland Oy, Destia Oy and Oy VR-Rata Ab, Tekla Oyj) and two of the main owners of the bridges in Finland, Finnish Transport Agency and the Public Works Department of Helsinki City. A work part was done to study and develop the numbering of the different bridge parts and the logic included. Two different modeling software was studied and considered, i.e., Tekla Structures and Solidworks. The most important general guidelines were identified first, a draft for the public guidelines was created and commented by the other partners included, and finally published by the Finnish Transport Agency.

\section{Results}

The final version of the National Guidelines for Bridge Information Modeling can be uploaded from the web site of the Finnish Transport Agency: http://alk.tiehallinto.fi/julkaisut/pdf3/lo_201108_siltojen_tietomalliohje_web.pdf

The guidelines contains following chapters:

(1) Description of modeling, model detail levels and model utilization in each of the design phases of a bridge. The phases are preliminary design, general design, bridge design, construction design, and renovation planning.

(2) Information model contents, technical guidelines discussion, such as coordinate systems, numbering of parts and model detail accuracy levels. Also description on how to report the status of a model and discussion about the as-built model.

(3) Design blueprints and how the $3 d$ modeling process affects them.

(4) Quality control, how it should be done by the design office and what materials will be needed by the public administration to check the plans.

(5) Model utilization at work sites.

(6) Model handovers, what are the legal points related to handing over the models to the different parties in a bridge construction project.
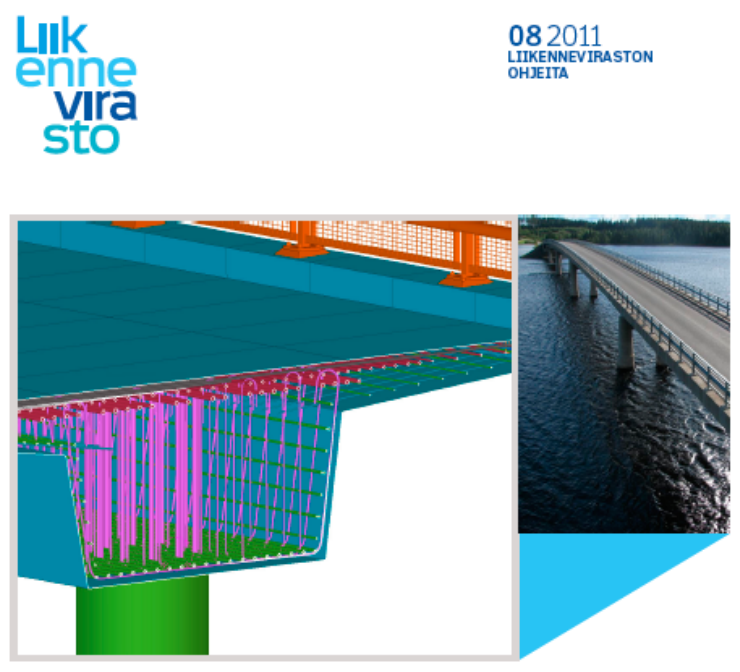

\section{Siltojen tietomalliohje}

\subsubsection{1}

Fig.3. The cover of the National Guidelines for Bridge Information Modeling in Finland (The Finnish Transport Agency).

Also a form containing the key issues that need to be agreed between the buyer of the information model (usually Finnish road administration) and the designer was developed. The form contains general information about the bridge project, list of parties involved, what starting information is available (laser scanned terrain models etc.), description of the details that are not yet accurately added to the model in each design phase, issues regarding model hando- 
vers to third parties, and what information will the asbuilt model contain, will as-built measurements and other information be inserted into the model.

\section{ConClusion}

National bridge modeling guidelines will speed the transition of the public administration and the private sector to 3-D modeling and. Overall, the transition to using 3-D information models for bridge construction projects is clearly inevitable as more and more bridge projects are being designed via information modeling in Finland. Nearly every design consultant office is gearing for information modeling. Also general contractors are frantically working to develop their processes towards using data from information models and to reduce waste in construction work.

\section{HB 138 MODELLGRUNNLAG \\ Krav til grunnlagsdata og modeller}

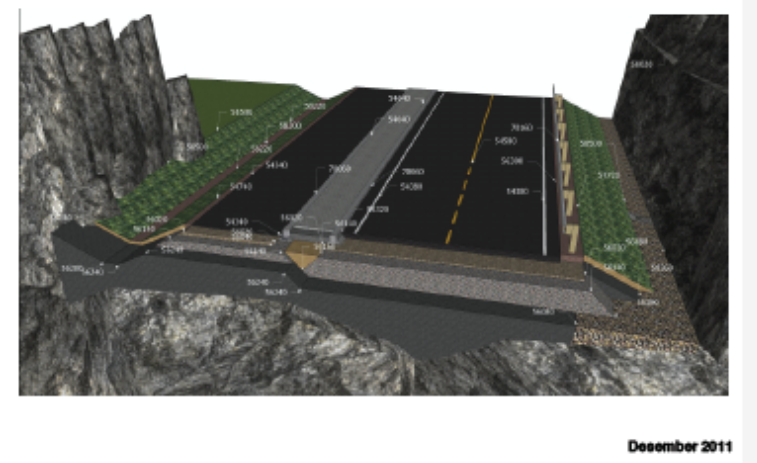

Fig. 4. The cover of the National Guidelines for Infra Information Modeling in Norway (Statensvegvesen, Norway, 2012). This draft has been a model for the development work, which is right now active in Finland.

Related to the new guidelines, there is a large research project, called RYM PRE (Process ReEngineering) at active phase in Finland. The aim is to develop wider building information modeling (BIM) guidelines and requirements to the all extension of infra construction activities in Finland. In addition, there are a group of work packets, where the aim is to continue the development work of the BIM guidelines for building construction sector. Also the research collaboration of BIM between infra and building sector has been studied and is about to start.

The future work is focused to test the guidelines for bridge modeling, based on the experiences got to develop the next version of the guidelines, combine that together with the guidelines for modeling of roads, railways, tunnels and dredging process, which are to be developed within RYM PRE InfraFINBIM research project. This research group is very interested in and is looking for international collaboration with other countries in this work.

More information can be found from the website: http://www.rym.fi/en/programs/builtenvironmentproce ssreengineeringpre/

\section{References}

1. Pulkkinen, P., Karjalainen, A., Heikkilä, R., " $5 D$ Bridge - Development of 5D Process and Tools for Bridge Engineering. IABSE (International Association for Bridge and Structural Engineering)", Information and Communication Technology for Bridges, Buildings and Construction Practice, Helsinki, Finland, pp. 68-69, 2008.

2. Heikkilä, R., Pulkkinen, P., Karjalainen, A., Jaakkola, M., "On the Economy and Benefits of 3-D Design Method in Bridge Engineering", ISARC'2005, The 22nd International Symposium on Automation and Robotics in Construction, 11-14 September 2005, Ferrara, Italy, pp. 70, 2005.

3. Heikkilä, R., Jaakkola, M., Pulkkinen, P., Modelling Measurements and Measuring Models - Problems and Solutions of 3-D Geometrical Control in Concrete Bridge Engineering. ISARC'2004, 21st International Symposium on Automation and Robotics in Construction, 21-25 September 2004. Jeju, Korea, pp. 81-84, 2004.

4. Heikkilä, R., Jaakkola, M., Pulkkinen, M., "Connecting 3-D Concrete Bridge Design to 3-D Site Measurements", ISARC'2003, 20th International Symposium on Automation and Robotics in Construction, 21-24 September 2003. Eindhoven, the Netherlands, pp. 259-264, 2003.

5. Kivimäki, T., Heikkilä, R., "Integrating 5D Product Modelling to On-site 3D Surveying of Bridges", ISARC'2009, The 26th International Symposium on Automation and Robotics in Construction, 24-27 June 2009, Austin, Texas, U.S.A., pp. 445-450, 2009.

6. Kivimäki, T., Heikkilä, R., "Bridge Information Modelling (BrIM) and Model Utilization at Worksites in Finland", ISARC'2010, The 27th International Symposium on Automation and Robotics in Construction, 25-27 June 2010, Bratislava, Slovakia, pp. 505-513. 2010. 